\title{
Anticancer effects of garlic and garlic-derived bioactive compounds and its potential status as functional food
}

\author{
Jacky Zong and Danik M. Martirosyan
}

Functional Food Institute, Dallas, TX 75252, USA

Corresponding author: Jacky Zong, Functional Food Institute, Dallas, TX 75252, USA

Submission Date: March 21 ${ }^{\text {st }}$, 2018, Acceptance Date: June $28^{\text {th }}$, 2018, Publication Date: June $30^{\text {th }}, 2018$

Citation: Zong J., Martirosyan D.M., Anticancer Effects of Garlic and Garlic-derived Bioactive Compounds and its Potential Status as Functional Food. Bioactive Compounds in Health and Disease 2018; 1(2): 16-35. DOI: https://doi.org/10.31989/bchd.v1i2.530

\begin{abstract}
Background: Garlic or Allium savitum has long been used to treat various diseases, including cancer. The anticancer effects of garlic are linked to several garlic-derived organosulfur compounds, including allicin, ajoene, DAS, DADS, DATS, and SAMC. Animal and in vitro studies have demonstrated that garlic bioactive compounds may prevent cancer through mechanisms such as inducing cell cycle arrest, promoting apoptosis, and inhibiting angiogenesis in different cancer cells. Observational studies, including case-control and cohort studies, have been conducted to confirm the protective effect against colorectal, gastric, and other cancers associated with garlic-derived bioactive compounds and raw garlic consumption. However, the results of these studies are mixed. We analyzed cell and animal studies in addition to epidemiological studies using the FDA's evidence-based review system for health claims and FFC's proposed standard for evaluating and developing functional food. Through our analysis, we concluded garlic is not a functional food due to the inconclusive data from observational studies and insufficient evidence from randomized clinical trials.
\end{abstract}

Keywords: Garlic, cancer, allicin, bioactive compound, functional food

\section{INTRODUCTION}

The first use of garlic Garlic dates back to thousands of years ago. Ancient civilizations like the Egyptians, Chinese, Greeks, Romans, and Indians used garlic as a food ingredient and medicine. Garlic originated from Central Asia and used in many cultures as a performance-enhancing medicine. For example, early Greek Olympic athletes were given garlic to improve their performance. Similarly, soldier's diets often included garlic. Both Greeks and Romans believed garlic could provide extra strength and courage for their soldiers. Garlic was used for other medical purposes as well. For example, an ancient text from India 2000 years ago described the use of 
garlic as a treatment for heart disease and arthritis. Several other historical documents from India and China also mentioned using garlic to treat digestive issues and fatigue $[1,2]$.

The well-documented medicinal use of garlic throughout human civilization is one of the major reasons for the widespread consumption of garlic today. In 2016, more than 26 million metric tons of garlic were produced globally, with China accounting for $80 \%$ of the production [2]. In the United States, garlic consumption steadily increased since the 1980s to about 2.6 pounds per capita. The rise in demand for garlic is likely due to the increased public acceptance of garlic's flavor profile, reported potential health benefits of garlic, and use of garlic in dietary supplements [3]. Research has focused on garlic as a potential food component for the prevention of diseases like hypertension, atherosclerosis, and cancer. Garlic prevents the development of diseases through mechanisms linked to different bioactive compounds isolated from garlic. These compounds, such as allicin, ajoene, diallyl sulfide (DAS), diallyl disulfide (DADS), and diallyl trisulfide (DATS) are not only responsible for the possible prevention of diseases but also for the distinct flavors and odors of garlic.

Because of the health potential of these bioactive compounds, garlic is considered by many to be a functional food. While there is no legal definition for the term "functional food," the Functional Food Center (FFC) defines functional foods as "natural or processed foods that contain biologically-active compounds; which, in defined, effective non-toxic amounts, provide a clinically proven and documented health benefit utilizing specific biomarkers, for the prevention, management, or treatment of chronic disease or its symptoms"[4].

The objective of this review is to examine recent findings on garlic and its bioactive compounds and cancer. First, we examined preliminary studies, such as animal and in vitro studies, investigating the effects of various garlic-derived bioactive compounds on cellular pathways associated with cancer. Next, we evaluated evidence from epidemiological studies on the relationship between raw garlic consumption and cancer risks. With these findings, the FDA's evidence-based review system for health claims, and the FFC's proposed standard for evaluating and developing functional foods, we analyzed the efficacy of garlic on cancer prevention, management, or treatment and the status of garlic as a functional food.

\section{GARLIC-DERIVED BIOACTIVE COMPOUNDS}

Garlic or Allium sativum is a rich source of bioactive compounds, particularly organosulfur compounds. Garlic-derived organosulfur compounds are categorized into two major classes: Lcysteine sulfoxides and $\gamma$-glutamyl-L-cysteine peptides. S-allyl-L cysteine sulfoxide, which is commonly known as alliin, is the major constituent of L-cysteine sulfoxides found in whole garlic. When fresh garlic cloves are chopped, crushed, or chewed, an enzyme called allinase is released. Allinase converts the naturally-occurring alliin to allicin, a thiosulfinate responsible for the distinctive aroma of garlic. Allicin can also be broken down to form various other organosulfur compounds. These compounds include allyl sulfides like diallyl sulfide (DAS), diallyl disulfide (DADS), diallyl trisulfide (DATS), ajoene, S-allymercaptogultathione (SAMG), Sallymercaptocysteine (SAMC), and many other second metabolites derived from allicin (Figure 1). $\gamma$-glutamyl-L-cysteine peptides are a group of hydrophilic peptides found in garlic. $\gamma$-glutamylS-allyl-L-cysteine, like alliin, is found in whole garlic and is an example of a $\gamma$-glutamyl-L-cysteine peptide. Other major $\gamma$-glutamyl-L-cysteine peptides found in garlic and garlic products include 
S-allyl-L-cysteine (SAC), trans-5-1-propenyl-L-cysteine, S-methyl-L-cysteine, and Sallylmercaptocysteine.

Many of these organosulfur derivatives have been shown to exhibit properties beneficial to human health, including anticancer properties. Accordingly, we will discuss studies examining the molecular mechanism of various garlic-derived bioactive compounds on cancer through various cellular pathways.

Figure 1. Chemical structures of major bioactive compounds found in garlic and garlic products

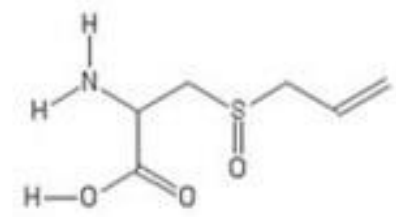

S-allyl-L-cysteine sulfoxide (alliin)

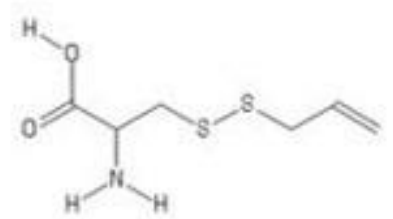

S-allym erca ptacysteine (SAMC)

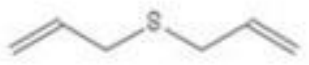

Diallyl sulfide (DAS)

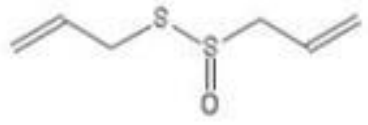

Ally1 2-propenethiosulfinate (allicin)

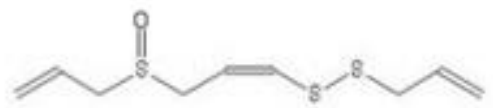

(Z)-ajoene

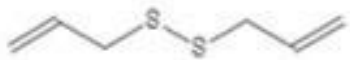

Diallyl disulfide (DADS)

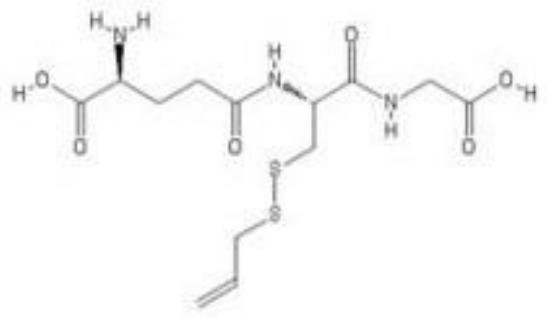

S-allym etcaptoglutathione. (SAMG)

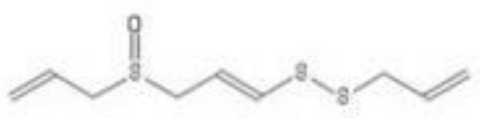

(E)-ajoene

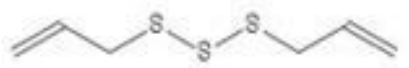

Diallyl trisulfide

(DATS)

\section{Induction of Cell Cycle Arrest}

Many in vivo and in vitro studies have observed cell cycle arrest, primarily in the G2/M phase, as a mechanism induced by organosulfur compounds like allicin, DADS, DATS, ajoene, and SAMC in different cancer cell lines by affecting various components of the cellular pathway [5]. DADS, DATS have shown to reduce the expression of $\mathrm{Cdc} 25 \mathrm{C}$, a protein phosphatase responsible for the dephosphorylation of threonine-14 and tyrosine-15 on the cyclin-dependent kinase $1(\mathrm{Cdk} 1) /$ cyclinB complex $[6,7,8,9]$. The protein complex is an important maturation promoting factor (MPF) for the initiation of cell mitosis. Without the dephosphorylation of threonine-14 and tyrosine-15, the Cdk1/cyclinB complex cannot phosphorylate other target proteins that are necessary to begin mitosis. MPF is also an important molecule during the process of mitosis. For 
example, the progression from metaphase and anaphase during mitosis requires MPF-induced activation of a ubiquitin ligase called the anaphase-promoting complex (APC).

APC contains various subunits, including Cdc27, Cdc20, and Cdh1. APC is activated when its subunits are dephosphorylated. Once it is activated, APC then ubiquitinates a protein called securin. Securin is naturally present in cells binding to another protein called separase. When securin is ubiquitinated by APC, separase is released from the protein complex and targets Scc1. $\mathrm{Scc} 1$ is a component of the protein complex cohesin, a protein ring that connects sister chromatids during the metaphase. The degradation of cohesin by separase is necessary for the separation of sister chromatids during the anaphase of mitosis. Degradation of other crucial molecular structures during mitosis can also lead to cell cycle arrest. Z-ajoene has been found to induce mitotic arrest in HL60 cells by disassembling microtubules. Microtubules play an important role as the major component of the mitotic spindles which pull apart sister chromatids during the anaphase and metaphase of mitosis [10].

DATS have been demonstrated to promote the inactivation of APC by phosphorylation of APC subunits in LNCaP cells and HCT-116 cells [11]. DADS have also been shown to induce G2/M phase cell cycle arrest by increase in reactive oxygen species (ROS) production. ROS causes DNA damage which leads to cell cycle arrest to repair damaged DNA. DNA damage stimulates p53 protein which is known as a tumor suppressor and is a regulator for another protein called p21. The p21 protein acts as an inhibitor for Cdk, similar to that found in the Cdk1/cyclinB complex. Several studies have demonstrated an increase in ROS production and p53 protein expression after treating cancer cells with DADS $[12,13]$. One study also observed SAMC inducing G0/G1 phase cell cycle arrest by upregulation of p53 and p21 in breast cancer cells in a time and dose-dependent manner [14]. Similarly, allicin increased p53 and p21 and promoted G2/M phase arrest in esophageal and gastric cancer cells. $[15,16]$. Another mechanism associated with DNA damage can lead to G2 cell cycle arrest. DNA damage caused by ROS can prevent cells from initiating mitosis due to the $\mathrm{G} 2$ cell cycle checkpoint. This mechanism is mediated by protein kinase Chk1, which deactivates $\mathrm{Cdc} 25$ through phosphorylation in the presence of unreplicated or damaged DNA. Inactivation of Cdc25 prevents the activation of MPF, leading to G2 cell cycle arrest. Studies have demonstrated the importance of Chk1 in DATS-induced cell cycle arrest in prostate and colon cancer cells $[9,11,17]$.

\section{Promotion of Apoptosis}

Inhibition of apoptosis or programmed cell death is an essential mechanism that enables cancer cells to grow uncontrollably in the body. Consequently, promotion of apoptosis in cancer cell has been a major focus in cancer research. Various garlic-derived bioactive compounds have shown promising results in inducing apoptosis in cancer cells, such as DAS, DADS, DATS, ajoene, and SAMC. There are two major pathways in apoptosis: intrinsic and extrinsic. Extrinsic pathways begin with signals received from outside of the cells. In many cases, this pathway is initiated by Fas ligands (FasL) found on the surface of T lymphocytes. The targeted cells have a corresponding surface receptor for FasL, known as Fas receptors (FasR).

Another similar ligand-receptor system is the TNF- $\alpha$ /TNFR1 model. The binding of the ligand to the receptor in both of these models lead to the binding of adaptor protein FADD and TRADD, respectively. The adaptor proteins are responsible for activating caspase- 8 and subsequently 
caspase-3, protease enzymes that break down cellular structure during apoptosis. Organosulfur compounds such as allicin have been shown to induce apoptosis through the extrinsic pathway by upregulation of caspase- 3 and 8 and TNF and Fas cell surface receptor activities $[18,19,20]$. Diallyl disulfide and diallyl trisulfide have also caused cancer cell death by increasing expression of Fas receptors [21, 22, 23].

The intrinsic pathway of apoptosis begins within the cell, in the mitochondrial membrane. Two important sets of proteins are involved: anti-apoptotic and pro-apoptotic protein. Naturally, Anti-apoptotic proteins, including Bcl-2 and Bcl-XL, bind to pro-apoptotic proteins, such as BAX and BAK, to prevent apoptosis from occurring. In cases where DNA damage or lack of survival signals occur, anti-apoptotic proteins are blocked from binding to pro-apoptotic proteins. Proteins such as BAX and BAK puncture holes in the mitochondrial membranes, allowing cytochrome $\mathrm{C}$ to enter the cytoplasm. In the cytoplasm, cytochrome $C$ then binds the Apaf-1 proteins to form a complex that activates various caspases to begin degradation of cell structure. Many garlic-derived organosulfur compounds exhibit pro-apoptotic activity by affecting the intrinsic pathway.

As mentioned before, generation of ROS by DADS and other garlic bioactive compounds lead to DNA damage. The presence of DNA damage is a condition that often begins the pro-apoptotic process by preventing anti-apoptotic proteins from binding to pro-apoptotic proteins. The direct inhibition of the the expression of anti-apoptotic proteins is another mechanism to promote cancer cell apoptosis, as demonstrated by various studies on the effect of ajoene on apoptosis in leukemia cells [24, 25]. Similarly, induction of apoptosis by reduced expression of pro-apoptotic proteins such as Bcl-2 and Bcl-XL, reduced Bcl-2/Bax interaction, elevated caspase-3, -8, and -9 activity, increased cytochrome $\mathrm{C}$ release, and increased Apaf-1 protein levels have been demonstrated with DATS [26, 27, 28, 29, 30, 31, 32], DADS [33, 34], DAS [32,35, 36, 37], allicin [19, 38, 39, 40, 41], and SAMC [42].

\section{Inhibition of Angiogenesis}

Angiogenesis is the natural process of new blood vessel formation in the body. However, it is also a crucial mechanism for the growth of cancer cells. To sustain continual growth, cancer cells promote angiogenesis to obtain the necessary nutrients from nearby blood vessels. It is also a preliminary step for metastasis or the spreading of cancer cells from an initial site to a secondary site. Cancer cells initiate angiogenesis by releasing pro-angiogenic molecules such as vascular endothelial growth factor (VEGF). Surface receptors on the endothelial cells of the nearby capillary, known as the vascular endothelial growth factor receptor 2 (VEGFR2), respond to proangiogenic factors by releasing proteolytic enzymes including matrix metalloproteinase (MMP). MMP and other proteolytic enzymes are responsible for breaking down the basement membrane and extracellular matrix that would otherwise block the new blood vessel from reaching the tumor cells from the nearby capillary. Continual release of VEGF from the tumor cells stimulates the migration of the endothelial cells towards the tumor site and eventually achieve tumor vascularization. Garlic-derived bioactive compounds have shown to target components involved in angiogenesis to inhibit tumor growth. Treatment with allicin has shown to reduce concentration and mRNA expression of VEGF [43, 44, 45, 46] and MMP [47, 48], as well as activation of VEGFR2 [49]. Downregulation of MMP and VEGF concentration and expression were also exhibited by DAS [50], DADS [50, 51], DATS [50, 52, 53,5 4], and alliin [55]. 


\section{Human Clinical Studies}

While many studies on garlic-derived bioactive have been conducted using cell culture and animal models, few human clinical trials can be found. One of these studies by Li et al. [56] examined the effect of $200 \mathrm{mg} / \mathrm{d}$ of synthetic DATS and $100 \mathrm{ug}$ of selenium every other day one month per year for a total of three years on the risk for gastric cancer among the Chinese population. The doubleblind intervention study selected 2526 treatment and 2507 control subjects aged 35-74 years old with either a medical history of stomach disorder, family history of tumor, or smoking and/or alcohol consumption. A five-year follow-up was conducted after the intervention. The results indicated that the relative risk for the entire intervention group was 0.67 (95\% CI: 0.43-1.03) and 0.48 (95\% Cl:0.21-1.06) for malignant tumors and gastric cancer, respectively.

Furthermore, the relative risk for malignant tumor 0.51 (95\% CI: $0.30-0.85$ ) and gastric cancer 0.36 (95\% CI: 0.14-0.92) in men indicated that supplementation of DATS may exhibit preventative effects against gastric cancer. Another intervention study following the same methodology as the previous study included 2639 treatment and 2664 control subjects selected from the rural area of China in Qixin County where gastric cancer is prevalent. Results from the five-year follow-up revealed that the relative risk for malignant tumor $(0.49,95 \% \mathrm{Cl}: 0.26-0.88)$ and gastric cancer $(0.30,95 \% \mathrm{Cl}: 0.12-0.76)$ in men were statistically significant [57].

However, it remains unclear whether DATS supplementation is solely responsible for the decreased risk of gastric cancer in these studies, as selenium has long been identified as a potential anticancer agent [58]. Moreover, a total of only three months of DATS administration is not adequate to confirm a correlation between DATS supplementation and reduced risk of gastric cancer. As a result, further clinical studies must be conducted before drawing conclusions on the anticancer effect of DATS and other allyl sulfides.

\section{WHOLE GARLIC CONSUMPTION AND CANCER}

Due to the promising results of the anticancer effects of garlic-derived bioactive compounds demonstrated on various cancer cell lines, epidemiological studies have been conducted to validate similar effects on cancer can be found in human beings after consumption of whole garlic over time. The majority of the epidemiological studies investigating the correlation between garlic consumption and risk of cancer so far were observational studies, such as cohort studies and casecontrol studies. Colorectal and gastric cancer are the predominant cancers examined by the selected epidemiological studies. However, garlic's effect on several other cancers such as breast, prostate, and lung cancer have also been reviewed.

\section{Colorectal Cancer}

Colorectal cancer refers to tumors located in the colon or rectum. Colorectal cancer has been a primary focus of many cohort and case-control studies investigating the effects of garlic consumption on cancer. However, results from the studies have been mixed. A case-control study conducted by Levi et al. [59] examined the relationship between food groups and colorectal cancer risk. The five-year study included 223 colorectal cancer patients and 491 controls. The results from the study indicated a statistically significant inverse relationship between garlic consumption and risk of colorectal cancer. The odds ratio was 0.32 (95\% CI: 0.18-0.57) when comparing the highest tertile of intake to the lowest tertile of intake. 
Table 1. Epidemiological studies on garlic consumption and colorectal cancer risk.

\begin{tabular}{|c|c|c|c|c|c|c|}
\hline Study & Country & $\begin{array}{l}\text { Level of } \\
\text { evidence }\end{array}$ & Subjects & Serving & $\begin{array}{l}\text { Hazard } \\
\text { Risk/Relativ } \\
\text { e Risk/Odds } \\
\text { Ratio (95\% } \\
\text { CI) }\end{array}$ & Main Findings \\
\hline $\begin{array}{l}\text { Levi et al. } \\
\text { 1999[59] }\end{array}$ & Switzerland & $\begin{array}{l}\text { Case- } \\
\text { control }\end{array}$ & $\begin{array}{l}223 \text { cases } \\
491 \text { controls }\end{array}$ & $\begin{array}{l}\text { Highest } \\
\text { tertile of } \\
\text { intake }\end{array}$ & $\begin{array}{l}\text { OR } \\
0.32(0.18- \\
0.57)\end{array}$ & $\begin{array}{l}\text { Statistically significant } \\
\text { inverse relationship } \\
\text { between garlic } \\
\text { consumption and risk of } \\
\text { cancer }\end{array}$ \\
\hline $\begin{array}{l}\text { Giovannucci } \\
\text { et al. } \\
1994[60]\end{array}$ & USA & $\begin{array}{l}\text { Cohort } \\
\text { study }\end{array}$ & $\begin{array}{l}205 \text { cases } \\
47,949 \\
\text { controls }\end{array}$ & $\begin{array}{l}>2 \\
\text { servings/w } \\
\text { eek }\end{array}$ & $\begin{array}{l}\mathrm{RR} \\
0.77(0.51- \\
1.16)\end{array}$ & $\begin{array}{l}\text { Strong, non-statistically } \\
\text { significant inverse } \\
\text { association between } \\
\text { garlic intake and risk of } \\
\text { cancer }\end{array}$ \\
\hline $\begin{array}{l}\text { Le } \\
\text { Marchand et } \\
\text { al 1997[61] }\end{array}$ & USA & $\begin{array}{l}\text { Case- } \\
\text { control }\end{array}$ & $\begin{array}{l}1192 \text { cases } \\
1192 \\
\text { controls }\end{array}$ & $\begin{array}{l}\text { Highest } \\
\text { quartile of } \\
\text { intake }\end{array}$ & $\begin{array}{l}\text { OR } \\
\text { Men } 0.7(0.5- \\
1.1) \\
\text { Women } \\
0.7(0.5-1.2)\end{array}$ & $\begin{array}{l}\text { Strong, non-statistically } \\
\text { significant inverse } \\
\text { association between } \\
\text { garlic intake and risk of } \\
\text { cancer }\end{array}$ \\
\hline $\begin{array}{l}\text { Galeone et } \\
\text { al. 2006[62] }\end{array}$ & Italy & $\begin{array}{l}\text { Case- } \\
\text { control }\end{array}$ & $\begin{array}{l}2280 \text { cases } \\
4765 \\
\text { controls }\end{array}$ & $\begin{array}{l}\text { High } \\
\text { tertile of } \\
\text { intake }\end{array}$ & $\begin{array}{l}\text { OR } \\
0.74(0.63- \\
0.86)\end{array}$ & $\begin{array}{l}\text { Non-statistically } \\
\text { significant inverse } \\
\text { association between } \\
\text { garlic consumption and } \\
\text { risk of cancer }\end{array}$ \\
\hline $\begin{array}{l}\text { Meng et al. } \\
2013 \text { [63] }\end{array}$ & USA & $\begin{array}{l}\text { Cohort } \\
\text { study }\end{array}$ & $\begin{array}{l}1029 \text { men } \\
1339 \\
\text { women }\end{array}$ & $\begin{array}{l}>1 \\
\text { serving/da } \\
y\end{array}$ & $\begin{array}{l}\text { HR } 1.00 \\
(0.71-1.42) \\
\text { HR } 1.21 \\
(0.94-1.57)\end{array}$ & $\begin{array}{l}\text { No association between } \\
\text { garlic intake and risk of } \\
\text { colorectal cancer }\end{array}$ \\
\hline $\begin{array}{l}\text { Annema et } \\
\text { al. 2011[64] }\end{array}$ & Australia & $\begin{array}{l}\text { Case- } \\
\text { Control } \\
\text { Study }\end{array}$ & $\begin{array}{l}325 \text { cases } \\
384 \\
\text { controls }\end{array}$ & $\begin{array}{l}\text { Highest } \\
\text { quartile } \\
(0.28+ \\
\text { servings/d) }\end{array}$ & $\begin{array}{l}\text { OR } \\
0.86(0.68- \\
1.09)\end{array}$ & $\begin{array}{l}\text { No statistically } \\
\text { significant correlation } \\
\text { was found between } \\
\text { garlic consumption and } \\
\text { cancer }\end{array}$ \\
\hline $\begin{array}{l}\text { McCullough } \\
\text { et al. } \\
2012[65]\end{array}$ & USA & $\begin{array}{l}\text { Cohort } \\
\text { study }\end{array}$ & $\begin{array}{l}42,824 \text { men } \\
56,876 \\
\text { women }\end{array}$ & $\begin{array}{l}>1 \\
\text { clove/day }\end{array}$ & $\begin{array}{l}\text { HR } 1.04 \\
(0.99-1.08) \\
\text { HR } 0.95 \\
(0.91-1.00)\end{array}$ & $\begin{array}{l}\text { Garlic consumption } \\
\text { associated with non- } \\
\text { significant increased } \\
\text { risk in men. }\end{array}$ \\
\hline
\end{tabular}


Other studies have also shown strong but non-statistically significant, inverse associations between garlic consumption and colorectal cancer risk [60,61, 62]. Several recent studies have not discovered any effects of garlic intake on colorectal cancer. Meng et al. [63] conducted followups of up to 24 years with 76,208 women from the Nurses' Health Study and 45,592 men from the Health Professionals Follow-up Study. After the follow-ups, 1029 men and 1339 women were diagnosed with colorectal cancer.

After adjusting for age, body mass index, smoking before age 30, history of colorectal cancer, history of endoscopy, regular aspirin use, physical activity, postmenopausal hormone use, consumption of processed meat, alcohol consumption, calcium intake, total folate intake, total vitamin D intake, and total energy intake, the hazard ratio associated with garlic intake for men and women were 1.00 (95\% CI: 0.71-1.42) and 1.21 (95\% CI: 0.94-1.57). The hazard ratios were calculated by comparing intake of $\geq 1$ serving/day and $<1$ serving/month. A case-control conducted in Australia also reported a similar outcome, with an adjusted odds ratio of 0.86 (95\% CI: 0.68 1.09) when comparing the highest quartile to the lowest quartile of garlic intake [64]. There has also been one cohort study that reported an increase risk of colorectal cancer associated with garlic intake. The Cancer Prevention Study II Nutrition Cohort collected information regarding garlic consumption from 42,824 men and 56,876 women. Following 7 years of follow-up, 1,130 cases, 579 men, and 551 women with colorectal cancer were identified. A non-statistically significant higher risk of colorectal cancer was associated with each additional serving of garlic per week in men $(\mathrm{HR}=1.04,95 \%$ CI: 0.99-1.08) [65].

\section{Gastric Cancer}

Many epidemiological studies reported positive outcomes related to garlic consumption and gastric cancer risk. Two case-control studies have demonstrated that high consumption of garlic was associated with significant decrease in risk of gastric cancer. The first study by Pourfarzi et al. [66] included 217 cases and 394 controls from an Iranian population. The study reported subjects who consumed garlic more than 3 times per week were at a significantly lower risk of gastric cancer when compared to those who only infrequently or never consumed garlic $(\mathrm{OR}=0.35,95 \% \mathrm{CI}$ : 0.13-0.95). Another case-control study carried out in Korea by Kim et al. [67] also observed a statistically significant decrease in gastric cancer risk associated with garlic intake, as the odds ratio when comparing the highest tertile to lowest tertile of intake was 0.53 (95\% CI: 0.27-1.02). Additionally, many studies conducted in different populations have reported non-statistically significant inverse relationship between high consumption of garlic intake and risk of gastric cancer $[68,69,70,71]$. 
Table 2. Epidemiological studies on garlic consumption and gastric cancer risk

\begin{tabular}{lllll}
\hline Study Country & $\begin{array}{l}\text { Level of } \\
\text { evidence }\end{array}$ & Subjects & Serving & Hazard \\
& & Risk/Relative \\
& & & Risk/Odds Ratio \\
& $(95 \%$ CI) &
\end{tabular}

\begin{tabular}{lllll}
\hline $\begin{array}{l}\text { Pourfarzi et } \\
\text { al. 2009[66] }\end{array}$ & Iran & $\begin{array}{l}\text { Case- } \\
\text { control }\end{array}$ & $\begin{array}{l}217 \text { cases } \\
394\end{array}$ & $>3$ \\
controls & times/wk & OR 0.35(0.13-0.95) & $\begin{array}{l}\text { High consumption of } \\
\text { garlic significantly } \\
\text { reduces risk of } \\
\text { stomach cancer }\end{array}$ \\
\hline
\end{tabular}

\begin{tabular}{|c|c|c|c|c|c|c|}
\hline $\begin{array}{l}\text { Kim et al. } \\
2002[67]\end{array}$ & Korea & $\begin{array}{l}\text { Case- } \\
\text { control }\end{array}$ & $\begin{array}{l}136 \text { cases } \\
136 \\
\text { controls }\end{array}$ & $\begin{array}{l}\text { Highest } \\
\text { tertile }\end{array}$ & OR $0.53(0.27-1.02)$ & $\begin{array}{l}\text { Increased intake of } \\
\text { garlic is associated } \\
\text { with significant } \\
\text { decrease in gastric } \\
\text { cancer risk. }\end{array}$ \\
\hline
\end{tabular}

\begin{tabular}{|c|c|c|c|c|c|c|}
\hline $\begin{array}{l}\text { Takezaki et } \\
\text { al 2001[68] }\end{array}$ & China & $\begin{array}{l}\text { Case- } \\
\text { control }\end{array}$ & $\begin{array}{l}187 \text { cases } \\
333 \\
\text { controls }\end{array}$ & Every day & OR $0.66(0.37-1.17)$ & $\begin{array}{l}\text { Non-statistically } \\
\text { significant inverse } \\
\text { association between } \\
\text { high consumption of } \\
\text { garlic and risk of } \\
\text { cancer }\end{array}$ \\
\hline
\end{tabular}

\begin{tabular}{|c|c|c|c|c|c|}
\hline $\begin{array}{l}\text { Gao et al. } \\
1999[69]\end{array}$ & China & $\begin{array}{l}\text { Case- } \\
\text { control }\end{array}$ & $\begin{array}{l}153 \text { cases } \\
234 \\
\text { controls }\end{array}$ & $\begin{array}{l}>1 \\
\text { time/wk }\end{array}$ & OR $0.31(0.22-0.44)$ \\
\hline
\end{tabular}

High consumption of garlic may be associated with reduced risk of stomach cancer

\begin{tabular}{|c|c|c|c|c|c|c|}
\hline $\begin{array}{l}\text { Zickute et } \\
\text { al. 2005[70] }\end{array}$ & Lithuania & $\begin{array}{l}\text { Case- } \\
\text { control }\end{array}$ & $\begin{array}{l}79 \text { cases } \\
1137 \\
\text { controls }\end{array}$ & $>1 \mathrm{k} / \mathrm{d}$ & OR $0.50(0.23-1.08)$ & $\begin{array}{l}\text { High consumption of } \\
\text { garlic may reduce risk } \\
\text { of stomach cancer }\end{array}$ \\
\hline
\end{tabular}

\begin{tabular}{lllllll}
\hline $\begin{array}{l}\text { Yassibas et } \\
\text { al. 2012[71] }\end{array}$ & Turkey & $\begin{array}{l}\text { Case- } \\
\text { control }\end{array}$ & $\begin{array}{l}106 \text { cases } \\
106\end{array}$ & $>1$ & OR 0.795(0.162- & $\begin{array}{l}\text { Non-statistically } \\
\text { significant inverse } \\
\text { controls }\end{array}$ \\
& & & & $3.899)$ & $\begin{array}{l}\text { relationship between } \\
\text { high garlic } \\
\text { consumption and risk } \\
\text { of gastric cancer }\end{array}$ \\
& & & & & $\begin{array}{l}\text { of gay } \\
\end{array}$ \\
& & & & &
\end{tabular}


Table 3. Epidemiological studies on garlic consumption and breast, prostate, and lung cancer risk.

\begin{tabular}{|c|c|c|c|c|c|c|c|}
\hline Study & Country & $\begin{array}{l}\text { Level of } \\
\text { evidence }\end{array}$ & Subjects & $\begin{array}{l}\text { Type of } \\
\text { cancer }\end{array}$ & Serving & $\begin{array}{l}\text { Hazard } \\
\text { Risk/Relative } \\
\text { Risk/Odds } \\
\text { Ratio (95\% CI) }\end{array}$ & Main Findings \\
\hline
\end{tabular}

\begin{tabular}{|c|c|c|c|c|c|c|}
\hline $\begin{array}{l}\text { Challier } \\
\text { et al. } \\
1998[72]\end{array}$ & France & $\begin{array}{l}\text { Case- } \\
\text { control }\end{array}$ & $\begin{array}{l}345 \text { cases } \\
345 \text { controls }\end{array}$ & Breast & $\begin{array}{l}\text { Weekly } \\
\text { frequency } \\
>16\end{array}$ & $\begin{array}{l}\text { OR } 0.3(0.17- \\
0.52)\end{array}$ \\
\hline
\end{tabular}

Statistically significant inverse association between garlic consumption and breast cancer risk.

\begin{tabular}{|c|c|c|c|c|c|c|c|}
\hline $\begin{array}{l}\text { Pourzan } \\
\text { d et al. } \\
2016[73]\end{array}$ & Iran & $\begin{array}{l}\text { Case- } \\
\text { control }\end{array}$ & $\begin{array}{l}56 \text { cases } \\
58 \text { controls }\end{array}$ & Breast & $\begin{array}{l}>0.9 \\
\text { g/day }\end{array}$ & $\begin{array}{l}\text { OR } 0.41(0.20- \\
0.83)\end{array}$ & $\begin{array}{l}\text { Statistically significant } \\
\text { inverse association } \\
\text { between high garlic } \\
\text { consumption and cancer } \\
\text { risk. }\end{array}$ \\
\hline $\begin{array}{l}\text { Levi et } \\
\text { al. } \\
1993[74]\end{array}$ & $\begin{array}{l}\text { Switze } \\
\text { rland }\end{array}$ & $\begin{array}{l}\text { Case- } \\
\text { control }\end{array}$ & $\begin{array}{l}107 \text { cases } \\
318 \text { controls }\end{array}$ & Breast & $\begin{array}{l}\text { Intermedi } \\
\text { ate tertile } \\
\text { of intake }\end{array}$ & OR 0.7 (0.4-1.1) & $\begin{array}{l}\text { Non-statistically } \\
\text { significant inverse } \\
\text { association between garlic } \\
\text { consumption and risk of } \\
\text { cancer }\end{array}$ \\
\hline $\begin{array}{l}\text { Key et } \\
\text { al. } \\
1997[75]\end{array}$ & UK & $\begin{array}{l}\text { Case- } \\
\text { control }\end{array}$ & $\begin{array}{l}328 \text { cases } \\
328 \text { controls }\end{array}$ & Prostate & $\begin{array}{l}\geq 2 \\
\text { servings/ } \\
\text { week }\end{array}$ & $\begin{array}{l}\text { OR } 0.64(0.39- \\
1.09)\end{array}$ & $\begin{array}{l}\text { Two or more servings of } \\
\text { garlic per week were } \\
\text { associated with } \\
\text { statistically non-significant } \\
36 \% \text { reduction in risk of } \\
\text { prostate cancer }\end{array}$ \\
\hline $\begin{array}{l}\text { Kirsh et } \\
\text { al. } \\
2007[76]\end{array}$ & US & Cohort & $\begin{array}{l}1338 \text { cases } \\
29,361 \\
\text { controls }\end{array}$ & Prostate & $\begin{array}{l}>1 \\
\text { time/wk }\end{array}$ & $\begin{array}{l}\text { RR } \\
0.88(0.76,1.03)\end{array}$ & $\begin{array}{l}\text { Non-statistically } \\
\text { significant inverse } \\
\text { association between garlic } \\
\text { consumption and risk of } \\
\text { cancer }\end{array}$ \\
\hline $\begin{array}{l}\text { Hsing et } \\
\text { al. } \\
2002[77]\end{array}$ & China & $\begin{array}{l}\text { Case- } \\
\text { control }\end{array}$ & $\begin{array}{l}238 \text { cases } \\
471 \text { controls }\end{array}$ & Prostate & $>2.14 \mathrm{~g} / \mathrm{d}$ & $\begin{array}{l}\text { OR } 0.47(0.31- \\
0.71)\end{array}$ & $\begin{array}{l}\text { Non-statistically } \\
\text { significant reduced risk of } \\
\text { cancer is associated with } \\
\text { high consumption of garlic } \\
\text { in men }\end{array}$ \\
\hline $\begin{array}{l}\text { Jin et al. } \\
2013[78]\end{array}$ & China & $\begin{array}{l}\text { Case- } \\
\text { control }\end{array}$ & $\begin{array}{l}1424 \text { cases } \\
4543 \text { controls }\end{array}$ & Lung & $\begin{array}{l}\geq 2 \text { times } \\
\text { per week }\end{array}$ & $\begin{array}{l}\text { OR } 0.56(0.44- \\
0.72)\end{array}$ & $\begin{array}{l}\text { Raw garlic consumption of } \\
\geq 2 \text { times per week is } \\
\text { inversely associated with } \\
\text { lung cancer with a } \\
\text { monotonic dose-response } \\
\text { relationship. }\end{array}$ \\
\hline $\begin{array}{l}\text { Myneni } \\
\text { et al. } \\
\text { 2016[79] }\end{array}$ & China & $\begin{array}{l}\text { Case- } \\
\text { control }\end{array}$ & $\begin{array}{l}399 \text { cases } \\
466 \text { controls }\end{array}$ & Lung & $\begin{array}{l}\leq 2 \text { times } \\
\text { per week } \\
\geq 2 \text { times } \\
\text { per week }\end{array}$ & $\begin{array}{l}\text { OR } 0.56(0.39- \\
0.81) \\
\text { OR } 0.50(0.34- \\
0.74)\end{array}$ & $\begin{array}{l}\text { Raw garlic consumption is } \\
\text { associated with a dose- } \\
\text { dependent reduced risk of } \\
\text { lung cancer }\end{array}$ \\
\hline
\end{tabular}




\section{Other Cancers}

Garlic intake has also been shown to protect against other cancers besides colorectal and gastric cancer. Two case-control studies [72, 73] performed in France and Iran both found a statistically significant inverse association between garlic intake and breast cancer risk, while another casecontrol study carried out in Switzerland observed a non-statistically significant reduction in breast cancer risk [74]. Likewise, case-control and cohort studies examining the relationship between garlic intake and prostate cancer reported promising results, suggesting positive effects of garlic consumption for prostate cancer [75, 76, 77]. Two recent studies conducted in China evaluating lung cancer risk and garlic intake also revealed reduced risk of cancer after consumption of whole garlic. The promising results from the observational studies will likely lead to many more epidemiological studies confirming the positive effect of garlic intake on various cancers.

\section{EVALUATING SCIENTIFIC EVIDENCE: FDA'S EVIDENCE-BASED REVIEW SYSTEM}

In the United States, the term functional food has not yet been defined by any legislation. Accordingly, the potential health benefits of functional foods are currently being communicated through nutrient and health claims, which are also applied to conventional foods and dietary supplements. Health claims are labeling claims which characterize a relationship between a food or food component and a disease or health-related condition. There are two types of health claims: authorized health claims and qualified health claims. Authorized health claims are approved health claims that achieved significant scientific agreement among qualified experts during the FDA scientific review of the claim. The FDA has established standards for evaluating significant scientific agreement of a health claim in order to provide confidence in the relationship described by the claim. Claims that are supported by scientific studies but do not meet the significant scientific agreement standard are called qualified health claims.

The significant scientific agreement standards established by FDA emphasize two major points when reviewing the scientific validity of a health claim: the totality of the publicly available evidence related to the food/disease relationship described in the claim and significant scientific agreement among qualified experts. The initial step for evaluating the totality of publicly available evidence requires collecting data from various types of studies. These studies include animal and in vitro studies, followed by epidemiological studies. Both observational and interventional studies are examined as part of the review process. Observational studies, such as cohort and case-control studies, serve as preliminary studies aimed to identify any association between a food and disease. However, due to the design of such studies, observational studies do not assign a defined dosage or nutrient intake level for the observed population. As a result, data from observational studies are not sufficient to support a causal relationship between a food and a disease. On the other hand, interventional studies, including randomized clinical trials, are designed to provide randomly assigned subjects with or without a treatment dosage of the food substance. Therefore, these studies provide stronger evidence for a food/disease causal relationship. Furthermore, the measurements reported in the studies is another component considered when reviewing data. Factors such as biomarkers, assessment method of dietary intake, and effects of other confounding factors are also considered when reviewing scientific data. After identifying studies to review, each individual study is examined closely. Aspects of the studies that are assessed include presence 
of bias or confounders, population studied, statistical methods, study intervention and outcome. After evaluating each selected study, the FDA determines whether the totality of the evidence supports the proposed health claim by determining the strength of the food/disease relationship. Strong significant evidence supporting the relationship should outweigh other evidence suggesting otherwise. The other half of the review process involves reaching a significant scientific agreement among qualified experts [80].

The sophisticated reviewing process of health claims used by FDA can be useful to evaluate the relationships between a functional food and a disease, such as that of garlic and cancer. For garlic, it has been shown that cell and animal model studies have confirmed the anticancer activity of bioactive compounds derived from garlic. Limited human clinical trials supplementing garlicderived organosulfur compounds along with selenium have also shown promising results on reducing cancer incidence. Additionally, many observational studies investigating the effect of garlic intake on cancer risks have reported a positive outcome, indicating an inverse relationship between high garlic consumption and cancer risk. However, other studies observed no correlation and even an increase in cancer risk associated with garlic intake.

Moreover, the lack of randomized clinical trials where subjects are prescribed defined amounts of garlic, undermines findings suggesting there is a positive effect of garlic on cancer. Due to the absence of high quality, randomized clinical trials using defined amounts of garlicderived bioactive compounds or raw garlic, it is difficult to conclude that the anticancer effects reported from cell and animal model studies and epidemiological studies are clinically proven. Accordingly, based on FDA's significant scientific agreement standards for reviewing health claims, it is difficult to establish a causal relationship between garlic and cancer. The conclusion is supported by Kim and Kwon (2008) [81], who conducted an analysis on the relationship between garlic intake and cancer risk using FDA's review system for health claims. Selected studies published between 1955 to 2007 were evaluated for scientific evidence. The analysis concluded that no strong evidence supported the relationship between garlic intake and risk of gastric, lung, and breast cancer. Furthermore, limited evidence was found for colon and prostate cancer.

\section{EVALUATING SCIENTIFIC EVIDENCE: FFC'S STANDARDS FOR FUNCTIONAL FOOD PRODUCTS}

The FFC has developed the following steps for creating functional food products:

1. Examine the link between a particular food and health benefits.

2. Run in vitro and in vivo studies with non-living and animal specimens, respectively. Find the bioactive compound responsible for the health benefit.

3. Establish a daily value and possible mechanism of bioactive compound.

4. Run human studies. This involves administering human-appropriate dosages of Food Bioactive Compounds and testing for adverse side effects.

5. Develop appropriate food vehicles for our bioactive compounds.

6. Obtain a special label for functional foods (with the information of daily usage amounts and length of usage).

7. Make approved health claims (FDA's Health Claims). 
8. Market to the public and educate them about the health benefits of functional food.

9. Run studies on populations to test for long-term effects and overall product effectiveness. Measure public attitudes toward functional food.

Sufficient data from animal and in vitro studies have identified several garlic bioactive compounds such as allicin, ajoene, DAS, DADS, DATS, and SAMC that are connected to the anticancer effects of garlic. Different mechanisms by which the garlic-derived bioactive compounds may prevent, manage, or treat cancer have been proposed and investigated in both animal and cell culture model studies. These mechanisms include induction of cell cycle arrest, promotion of apoptosis, and inhibition of angiogenesis.

Many epidemiological studies, primarily case-control and cohort studies, were conducted to verify the anticancer effects of garlic in human subjects. However, there were not as many large and randomized clinical trials demonstrating the efficacy of garlic in preventing, managing, or treating various types of cancers. Few clinical trials using garlic-derived bioactive compounds have been conducted but additional studies need to be repeated to confirm the results.

Clinical trials are also essential for determining an intake level that ensures the desired health effect is achieved. The identified intake level should include a defined daily dosage and number of days needed to consume at such dosage to achieve the desired effect. The currently available case-control and cohort studies did not identify a recommended daily dosage or usage period for garlic to prevent, manage, or treat cancer. Furthermore, the toxicity level and potential adverse effects must also be evaluated by the epidemiological studies. There were no reports of toxicity or adverse side effects associated with dietary garlic consumption reported in any of the studies analyzed.

Based on FFC's definition for functional foods, bioactive compounds are the backbone of the Functional Food products. Consequently, it is important to identify exactly which bioactive compounds are responsible for the observed health benefits. The next step towards identifying garlic as a functional food is determining the exact amount of bioactive compounds which in defined, effective, and non-toxic amounts provide a clinically proven and documented health benefit. This must be done by utilizing specific biomarkers. As a result, conducting randomized, controlled, and double-blind clinical studies are a necessary and subsequent step to confirm the anticancer effect of garlic and garlic-derived bioactive compounds and to officially consider garlic as a functional food.

\section{CONCLUSION}

Garlic-derived organosulfur compounds, including alliin, allicin, ajoene, DAS, DADS, DATS, and SAMC found in garlic and garlic products have been shown to exhibit anticancer effects in animal and in vitro studies. Through multiple cellular pathways, garlic bioactive compounds were able to induce cell cycle arrest and apoptosis inhibit angiogenesis in different cancer cell lines. Results from observational studies investigating the relationship between dietary garlic consumption and colorectal, gastric, prostate, breast, and lung cancer were inconclusive.

Both the FDA's evidence-based review system for health claim and FFC's proposed standards for evaluating functional food have highlighted the need for future large randomized clinical 
studies and other epidemiological studies to draw stronger conclusions on the efficacy of garlic on cancer prevention.

Specifically, the FFC recommend defining the appropriate dosages and length of treatment for garlic or garlic-derived bioactive compounds to ensure the desired health effects are achieved. They should be determined through clinical and epidemiological studies. However, before additional studies are reported and reviewed, garlic cannot be yet considered a functional food.

List of Abbreviations: diallyl sulfide, DAS; diallyl disulfide, DADS; diallyl trisulfide, DATS; functional food center, FFC; S-allymercaptogultathione, SAMG; S-allymercaptocysteine, (SAMC); S-allyl-L-cysteine, (SAC); maturation promoting factor, MPF; cyclin-dependent kinase 1, Cdk1; anaphase-promoting complex, APC. reactive oxygen species, ROS; Fas ligand, FasL; Fas receptor, FasR; tumor necrosis factor alpha, TNF- $\alpha$; tumor necrosis factor receptor 1, TNFR1; Fasassociated protein with death domain, FADD; TNFR1-associated death domain protein, TRADD; B-cell lymphoma 2, Bcl-2; Bcl-2 associated X protein; Bcl-2 homologous antagonist/killer, BAX; Apaf-1, apoptotic protease activating factor 1; vascular endothelial growth factor, VEGF; vascular endothelial growth factor receptor 2, VEGFR2; matrix metalloproteinase, MMP;

Competing Interests: The authors have no financial interests or any other conflicts of interest to disclose.

\section{REFERENCES}

1. Rivlin RS: Historical perspective on the use of garlic. J Nutr 2001, 131(3): 951S-954S.

2. Koch HP, Lawson LD: Garlic: the science and therapeutic application of Allium sativumL. and related species. Baltimore: Williams \& Wilkins; 1996.

3. Food and Agriculture Organization of the United Nations, Statistic Division (FAOSTAT) [http://www.fao.org/faostat/en/\#data/QC].

4. Martirosyan D, Pisarski K: Bioactive Compounds: Their Role in Functional Food and Human Health, Classifications, and Definitions. In Functional Foods and Cancer: Bioactive Compounds and Cancer. Volume 4. 1st edition. San Diego: Functional Food Center Inc; 2017: 238-277.

5. Iciek M, Kwiecien I, Wlodek L: Biological properties of garlic and garlic-derived organosulfur compounds. Environ Mol Mutagen 2009, 50(3): 247-265.

6. Knowles LM, Milner JA: Diallyl disulfide inhibits p34 cdc2 kinase activity through changes in complex formation and phosphorylation. Carcinogenesis 2000, 21(6): 11291134.

7. Yuan JP, Wang GH, Ling H, Su Q, Yang YH, Song Y, Tang RJ, et al.: Diallyl disulfideinduced G2/M arrest of human gastric cancer MGC803 cells involves activation of p38 MAP kinase pathways. World J Gastroenterol 2004, 10(18): 2731-2734.

8. Wallace GC, Haar CP, Vandergrift WA, Giglio P, Dixon-Mah YN, Varma AK, Das A: Multi-targeted DATS prevents tumor progression and promotes apoptosis in ectopic 
glioblastoma xenografts in SCID mice via HDAC inhibition. J Neuro-oncol 2013, 114(1): 43-50.

9. Xiao D, Herman-Antosiewicz A, Antosiewicz J, Xiao H, Brisson M, Lazo JS, Singh SV: Diallyl trisulfide-induced G 2-M phase cell cycle arrest in human prostate cancer cells is caused by reactive oxygen species-dependent destruction and hyperphosphorylation of Cdc25C. Oncogene 2005, 24(41): 6256-6268.

10. Li M, Ciu JR, Ye Y, Min JM, Zhang LH, Wang K, Leung-Tack J: Antitumor activity of Zajoene, a natural compound purified from garlic: antimitotic and microtubule-interaction properties. Carcinogenesis 2002, 23(4): 573-579.

11. Xiao D, Zeng Y, Singh SV: Diallyl trisulfide-induced apoptosis in human cancer cells is linked to checkpoint kinase 1-mediated mitotic arrest. Mol carcinogen 2009, 48(11): 10181029.

12. Song JD, Lee SK, Kim KM, Park SE, Park SJ, Kim KH, Park YC: Molecular mechanism of diallyl disulfide in cell cycle arrest and apoptosis in HCT-116 colon cancer cells. J Biochem Mol Toxic 2009, 23(1): 71-79.

13. Wu XJ, Kassie F, Mersch-Sundermann V: The role of reactive oxygen species (ROS) production on diallyl disulfide (DADS) induced apoptosis and cell cycle arrest in human A549 lung carcinoma cells. Mutat Res-Fund Mol M 2005, 579(1): 115-124.

14. Zhang H, Wang K, Lin G, Zhao Z: Antitumor mechanisms of S-allyl mercaptocysteine for breast cancer therapy. BMC Complem Altern M 2014, 14(1): 270.

15. Chen F, Li H, Wang Y, Gao M, Cheng Y, Liu D, Zhang J: Inhibition of allicin in Eca109 and EC9706 cells via G2/M phase arrest and mitochondrial apoptosis pathway. J Funct Foods 2016, 25: 523-536.

16. Ha MW, Yuan Y: Allicin induced cell cycle arrest in human gastric cancer cell lines. Chin J oncol 2004, 26(10): 585-589.

17. Herman-Antosiewicz A, Singh SV: Checkpoint kinase 1 regulates diallyl trisulfideinduced mitotic arrest in human prostate cancer cells. J Biol Chem 2005, 280(31): 2851928528.

18. Zhang M, Gao J, Wang H: Effect of Allicin on TRAIL-induced apoptosis in SKOV-3 cells in vitro. Hebei Med J 2011, 6: 012.

19. Zhang W, Ha M, Gong Y, Xu Y, Dong N, Yuan Y: Allicin induces apoptosis in gastric cancer cells through activation of both extrinsic and intrinsic pathways. Oncol Rep 2010, 24(6): 1585-1592.

20. Zhang ZM, Zhong N, Gao HQ, Zhang SZ, Wei Y, Xin H, Mei X, et al.: Inducing apoptosis and upregulation of Bax and Fas ligand expression by allicin in hepatocellular carcinoma in Balb/c nude mice. Chin Med J 2006, 119(5): 422-425.

21. Ma HB, Huang S, Yin XR, Zhang Y, Di ZL: Apoptotic pathway induced by diallyl trisulfide in pancreatic cancer cells. World J Gastroenterol 2014, 20(1): 193-203. 
22. Malki A, El-Saadani M, Sultan AS: Garlic constituent diallyl trisulfide induced apoptosis in MCF7 human breast cancer cells. Cancer Biol Ther 2009, 8(22): 2174-2184.

23. Altonsy MO, Madkour HI, Yousef RS, Andrews SC: Diallyl disulfide, from garlic oil, synthesizes human colonic adenocarcinoma cell line (Caco-2) to TNF-alpha-mediated apoptosis through up-regulation of membrane FAS levels. J Am Sci 2013, 9(3): 173-180.

24. Zheng D, Zhang S, Zhao S, Min J, Wang K, Liu S: Z-ajoene induces tumor cells to die by apoptosis. Chinese Sci Bull 1998, 43(13): 1135-1140.

25. Li M, Min JM, Cui JR, Zhang LH, Wang K, Valette A, Davrinche C, et al.: Z-ajoene induces apoptosis of HL-60 cells: involvement of Bcl-2 cleavage. Nutr Cancer 2002, 42(2): 241-247.

26. Xiao D, Choi S, Johnson DE, Vogel VG, Johnson CS, Trump DL, Lee YJ, et al.: Diallyl trisulfide-induced apoptosis in human prostate cancer cells involves c-Jun N-terminal kinase and extracellular-signal regulated kinase-mediated phosphorylation of Bcl-2. Oncogene 2004, 23(33): 5594-5606.

27. Xiao D, Zeng Y, Hahm ER, Kim Y, Ramalingam S, Singh SV: Diallyl trisulfide selectively causes Bax-and Bak-mediated apoptosis in human lung cancer cells. Environ Mol Mutagen 2009, 50(3): 201-212.

28. Li W, Tian H, Li L, Li S, Yue W, Chen Z, et al.: Diallyl trisulfide induces apoptosis and inhibits proliferation of A549 cells in vitro and in vivo. Acta Bioch Bioph Sin 2012, 44(7): 577-583.

29. Yu CS, Huang AC, Lai KC, Huang YP, Lin MW, Yang JS, Chung JG: Diallyl trisulfide induces apoptosis in human primary colorectal cancer cells. Oncol Rep 2012, 28(3): 949954.

30. Kim YA, Xiao D, Xiao H, Powolny AA, Lew KL, Reilly ML, Zeng Y, et al.: Mitochondriamediated apoptosis by diallyl trisulfide in human prostate cancer cells is associated with generation of reactive oxygen species and regulated by Bax/Bak. Mol Cancer Ther 2007, 6(5): 1599-1609.

31. Wang HC, Hsieh SC, Yang JH, Lin SY, Sheen LY: Diallyl trisulfide induces apoptosis of human basal cell carcinoma cells via endoplasmic reticulum stress and the mitochondrial pathway. Nutr Cancer 2012, 64(5): 770-780.

32. Karmakar S, Banik NL, Patel SJ, Ray SK: Garlic compounds induced calpain and intrinsic caspase cascade for apoptosis in human malignant neuroblastoma SH-SY5Y cells. Apoptosis 2007, 12(4): 671-684.

33. Nagaraj NS, Anilakumar KR, Singh OV: Diallyl disulfide causes caspase-dependent apoptosis in human cancer cells through a Bax-triggered mitochondrial pathway. $\mathrm{J}$ Nutr Biochem 2010, 21(5): 405-412. 
34. Lu HF, Sue CC, Yu CS, Chen SC, Chen GW, Chung JG: Diallyl disulfide (DADS) induced apoptosis undergo caspase-3 activity in human bladder cancer T24 cells. Food Chem Toxicol 2004, 42(10): 1543-1552.

35. Wu PP, Chung HW, Liu KC, Wu RS, Yang JS, Tang NY, Lo C, et al.: Diallyl sulfide induces cell cycle arrest and apoptosis in HeLa human cervical cancer cells through the p53, caspase-and mitochondria-dependent pathways. Int J Oncol 2011, 38(6): 1605-1613.

36. Shin HA, Cha YY, Park MS, Kim JM, Lim YC: Diallyl sulfide induces growth inhibition and apoptosis of anaplastic thyroid cancer cells by mitochondrial signaling pathway. Oral Oncol 2010, 46(4): e15-e18.

37. Chiu TH, Lan KY, Yang MD, Lin JJ, Hsia TC, Wu CT, Yang JS, et al.: Diallyl sulfide promotes cell-cycle arrest through the p53 expression and triggers induction of apoptosis via caspase-and mitochondria-dependent signaling pathways in human cervical cancer $\mathrm{Ca}$ Ski cells. Nutr Cancer 2013, 65(3): 505-514.

38. Wang Z, Liu Z, Cao Z, Li L: Allicin induces apoptosis in EL-4 cells in vitro by activation of expression of caspase-3 and-12 and up-regulation of the ratio of Bax/Bcl-2. Nat Prod Res 2012, 26(11): 1033-1037.

39. Oommen S, Anto RJ, Srinivas G, Karunagaran D: Allicin (from garlic) induces caspasemediated apoptosis in cancer cells. Eur J Pharmacol, 2004 485(1-3), 97-103.

40. Park SY, Cho SJ, Kwon HC, Lee KR, Rhee DK, Pyo S: Caspase-independent cell death by allicin in human epithelial carcinoma cells: involvement of PKA. Cancer Lett 2005, 224(1): 123-132.

41. Miron T, Wilchek M, Sharp A, Nakagawa Y, Naoi M, Nozawa Y, Akao Y: Allicin inhibits cell growth and induces apoptosis through the mitochondrial pathway in HL60 and U937 cells. J Nutr Biochem 2008, 19(8): 524-535.

42. Lee Y, Kim H, Lee J, Kim K: Anticancer activity of S-allylmercapto-L-cysteine on implanted tumor of human gastric cancer cell. Biol Pharm Bull 2011, 34(5): 677-681.

43. Zeng J, He X, Ma Y, Han M, Yu J, Xia H: Effect of allicin on the growth of hepatocellular carcinoma cells. Chinese J Gen Surg 2009, 7: 015.

44. Gao YJ, Yuan MB, Xin H, Wang Q, Shao HL: Effect of allicin on the regulation of VEGF mRNA expression in human hepatocellular carcinoma cells. Chin Pharm Bull 2001, 17(5): 531-533.

45. Gao Y, Liu YQ, Cao WK, Chen XF, Wan YY, Heng C, Xu LJ: Effects of allicin on invasion and metastasis of colon cancer LoVo cell line in vitro. Chinese Med J-Peking 2009, 89(20): 1382-1386.

46. Sela U, Brill A, Kalchenko V, Dashevsky O, Hershkoviz R: Allicin inhibits blood vessel growth and downregulates Akt phosphorylation and actin polymerization. Nutr Cancer 2008, 60(3): 412-420. 
47. Cai Q, Qin HZ, Chen KL: The effect and mechanism of allicin on the migration and invasion properties of human osteosarcoma U87 cells. J Xi'an Jiaotong U 2015, 36(2):271274.

48. Huang L, Song Y, Lian J, Wang Z: Allicin inhibits the invasion of lung adenocarcinoma cells by altering tissue inhibitor of metalloproteinase/matrix metalloproteinase balance via reducing the activity of phosphoinositide 3-kinase/AKT signaling. Oncol Lett 2017, 14(1): 468-474.

49. Wang W, Du Z, Nimiya Y, Sukamtoh E, Kim D, Zhang G: Allicin inhibits lymphangiogenesis through suppressing activation of vascular endothelial growth factor (VEGF) receptor. J Nutr Biochem 2016, 29: 83-89.

50. Lai KC, Hsu SC, Kuo CL, Yang JS, Ma CY, Lu HF, Tang NY, et al.: Diallyl sulfide, diallyl disulfide, and diallyl trisulfide inhibit migration and invasion in human colon cancer colo 205 cells through the inhibition of matrix metalloproteinase-2,-7, and-9 expressions. Environ Toxic 2013, 28(9): 479-488.

51. Huang J, Yang B, Xiang T, Peng W, Qiu Z, Wan J, Zhang L, et al.: Diallyl disulfide inhibits growth and metastatic potential of human triple-negative breast cancer cells through inactivation of the $\beta$-catenin signaling pathway. Mol Nutr Food Res 2015, 59(6): 10631075.

52. Xiao D, Li M, Herman-Antosiewicz A, Antosiewicz J, Xiao H, Lew KL, Zeng Y, et al.: Diallyl trisulfide inhibits angiogenic features of human umbilical vein endothelial cells by causing Akt inactivation and down-regulation of VEGF and VEGF-R2. Nutr Cancer 2006, 55(1): 94-107.

53. Lai KC, Hsu SC, Yang JS, Yu CC, Lein JC, Chung JG: Diallyl trisulfide inhibits migration, invasion and angiogenesis of human colon cancer HT-29 cells and umbilical vein endothelial cells, and suppresses murine xenograft tumour growth. J Cell Mol Med 2015, 19(2): 474-484.

54. Shin DY, Cha HJ, Kim GY, Kim WJ, Choi YH: Inhibiting invasion into human bladder carcinoma 5637 cells with diallyl trisulfide by inhibiting matrix metalloproteinase activities and tightening tight junctions. Int J Mol Sci 2013, 14(10): 19911-19922.

55. Mousa AS, Mousa SA: Anti-angiogenesis efficacy of the garlic ingredient alliin and antioxidants: role of nitric oxide and p53. Nutr Cancer 2005, 53(1): 104-110.

56. Li H, Li HQ, Wang Y, Xu HX, Fan WT, Wang ML, Sun PH, et al.: An intervention study to prevent gastric cancer by micro-selenium and large dose of allitridum. Chin Med J 2004, 117(8): 1155-1160.

57. Zheng GH, Li H, Fan WT, Li HQ: Study on the long-time effect on allitridum and selenium in prevention of digestive system cancers. Chin J of Epidemiol 2005, 26(2): 110-112. 
58. Lee EH, Myung SK, Jeon YJ, Kim Y, Chang YJ, Ju W, Seo HG, et al.: Effects of selenium supplements on cancer prevention: meta-analysis of randomized controlled trials. Nutr Cancer 2011, 63(8): 1185-1195.

59. Levi F, Pasche C, La Vecchia C, Lucchini F, Franceschi S: Food groups and colorectal cancer risk. Brit J Cancer, 1999 79(7-8): 1283-1287.

60. Giovannucci E, Rimm EB, Stampfer MJ, Colditz GA, Ascherio A, Willett WC: Intake of fat, meat, and fiber in relation to risk of colon cancer in men. Cancer Res 1994, 54(9): 2390-2397.

61. Le Marchand L, Hankin JH, Wilkens LR, Kolonel LN, Englyst HN, Lyu LC: Dietary fiber and colorectal cancer risk. Epidemiology 1997, 8(6):658-665.

62. Galeone C, Pelucchi C, Levi F, Negri E, Franceschi S, Talamini R, Giocosa A, et al.: Onion and garlic use and human cancer. Am J Clin Nutr 2006, 84(5): 1027-1032.

63. Meng S, Zhang X, Giovannucci EL, Ma J, Fuchs CS, Cho E: No association between garlic intake and risk of colorectal cancer. Cancer Epidemiol 2013, 37(2): 152-155.

64. Annema N, Heyworth JS, McNaughton SA, Iacopetta B, Fritschi L: Fruit and vegetable consumption and the risk of proximal colon, distal colon, and rectal cancers in a casecontrol study in Western Australia. J Acad Nutr Diet 2011, 111(10): 1479-1490.

65. McCullough ML, Jacobs EJ, Shah R, Campbell PT, Gapstur SM: Garlic consumption and colorectal cancer risk in the CPS-II Nutrition Cohort. Cancer Cause Control 2012, 23(10): 1643-1651.

66. Pourfarzi F, Whelan A, Kaldor J, Malekzadeh R: The role of diet and other environmental factors in the causation of gastric cancer in Iran - a population based study. Int $\mathrm{J}$ Cancer 2009, 125(8): 1953-1960.

67. Kim HJ, Chang WK, Kim MK, Lee SS, Choi BY: Dietary factors and gastric cancer in Korea: A case-control study. Int J Cancer 2002, 97(4): 531-535.

68. Takezaki T, Gao CM, Wu JZ, Ding JH, Liu YT, Zhang Y, Li SP, et al.: Dietary protective and risk factors for esophageal and stomach cancers in a low-epidemic area for stomach cancer in Jiangsu Province, China: comparison with those in a high-epidemic area. Cancer Sci 2001, 92(11): 1157-1165.

69. Gao CM, Takezaki T, Ding JH, Li MS, Tajima K: Protective Effect of Allium Vegetables against Both Esophageal and Stomach Cancer: A Simultaneous Case-referent Study of a High-epidemic Area in Jiangsu Province, China. Cancer Sci 1999, 90(6): 614-621.

70. Zickute J, Strumylaite L, Dregval L, Petrauskiene J, Dudzevicius J, Stratilatovas E: Vegetables and fruits and risk of stomach cancer. Medicina-Lithuania 2005, 41(9): 733740.

71. Yassibas E, Arslan P, Yalcin S: Evaluation of dietary and life-style habits of patients with gastric cancer: a case-control study in Turkey. Asian Pac J Cancer P 2012, 13(5): 22912297. 
72. Challier, B., Perarnau, J. M., Viel, J. F: Garlic, onion and cereal fibre as protective factors for breast cancer: a French case-control study. Eur J Epidemiol 1998, 14(8): 737-747.

73. Pourzand A, Tajaddini A, Pirouzpanah S, Asghari-Jafarabadi M, Samadi N, Ostadrahimi AR, Sanaat Z: Associations between dietary Allium vegetables and risk of breast cancer: A hospital-based matched case-control study. J Breast Cancer 2016, 19(3): 292-300.

74. Levi F, La Vecchia C, Gulie C, Negri E: Dietary factors and breast cancer risk in Vaud, Switzerland. Nutr Cancer 1993, 19(3): 327-335.

75. Key TJ, Silcocks PB, Davey GK, Appleby PN, Bishop DT: A case-control study of diet and prostate cancer. Brit J Cancer 1997, 76(5): 678-687.

76. Kirsh VA, Peters U, Mayne ST, Subar AF, Chatterjee N, Johnson CC, Hayes RB: Prospective study of fruit and vegetable intake and risk of prostate cancer. J Natl Cancer I 2007, 99(15): 1200-1209.

77. Hsing AW, Chokkalingam AP, Gao YT, Madigan MP, Deng J, Gridley G, Fraumeni Jr JF: (2002). Allium vegetables and risk of prostate cancer: a population-based study. J Natl Cancer I 2002, 94(21): 1648-1651.

78. Jin ZY, Wu M, Han RQ, Zhang XF, Wang XS, Liu AM, Zhou JY, et al.: Raw garlic consumption as a protective factor for lung cancer, a population-based case-control study in a Chinese population. Cancer Prev Res 2013, 6(7): 711-718.

79. Myneni AA, Chang SC, Niu R, Liu L, Swanson MK, Li J, Su J, Giovino GA, et al.: Raw garlic consumption and lung cancer in a Chinese population. Cancer Epidemiol Biomarkers Prev 2016, 25(4): 624-633.

80. US Food and Drug Administration: Guidance for industry: Significant scientific agreement in the review of health claims for conventional foods and dietary supplements. Washington, DC: US Department of Health and Human Services; 1999.

81. Kim JY, Kwon O: Garlic intake and cancer risk: an analysis using the Food and Drug Administration's evidence-based review system for the scientific evaluation of health claims. Am J Clin Nutr 2008, 89(1): 257-264.

82. Martirosyan DM, Singh J: A New Definition for Functional Food by FFC: Creating Functional Food Products Using New Definition. In Introduction to functional food science. 3rd edition. San Diego: Functional Food Center Inc; 2015: 10-24. 